ing high foreign language and cross-cultural skills (such as project-based learning with local students in a host country) can be an additional option for students to continue developing their competencies. Developing an environment for students to utilize and build on their experiences during super-short-term study abroad programs will be key to making this new trend an opportunity to nurture future "outward-looking" graduates.

DOI: http://dx.doi.org/ıo.6oI7/ihe.2018.94.10519

\section{Pathway Colleges: A New In- stitutional Form in Canada}

\section{Dale M. McCartney and Amy Scott Metcalfe}

Dale M. McCartney is a PhD candidate and Amy Scott Metcalfe is associate professor in higher education at the Department of Educational Studies, University of British Columbia, Canada. E-mails: dale.mccartney@alumni.ubc.ca and amy.metcalfe@ubc.ca.

Thternational undergraduate students represent an important source of tuition revenue for many higher education systems, especially in the context of declining support from austerity-focused governments. In an effort to increase international undergraduate recruitment, Canadian universities are creating partnerships with or directly hosting "pathway colleges." Pathway colleges are semiautonomous or privately operated institutions that have transfer agreements with partner universities to offer enrollment pathways for international students who lack the academic or linguistic credentials to allow direct entry to undergraduate degree programs at the university level. Whereas pathway colleges exist in other countries, the format is relatively new in Canada, where they have gone largely unexamined to this point. What little has been written on the topic has drawn attention to the colleges' reliance on part-time instructors, their potential to increase "corporatization" of the academy, and the possibility that some international students might be misled by the marketing materials regarding the likelihood of transfer to an established Canadian university. Considering these concerns, we call for increased attention to the policies and practices of pathway colleges. Drawing on Canadian data, we offer a brief typology of these institutions, identify some possible concerns about their impact on public higher education systems, and suggest some directions for future research.

To better understand this phenomenon, we studied the 96 institutions that belong to Universities Canada, a national advocacy organization for the sector. The pathway college relationship is becoming commonplace among public Canadian universities: our research revealed that 69 of the 96 institutions, or 72 percent of Canadian universities, had an affiliation with at least one pathway college. As pathway colleges are a new institutional model in Canada, there are significant variations in the form they take. Our research revealed three useful axes of comparison that give a sense of the general shape of the pathway college phenomenon in Canada: ownership, curriculum, and the transfer mechanism.

\section{OWNERSHIP}

We noted two forms of ownership within Canadian pathway colleges: private partnerships or colleges owned by public host institutions. Of the 69 universities that have an affiliation with a pathway program, 22 ( 32 percent) of them have affiliations with pathway colleges that are private, for-profit institutions. These private pathway colleges are usually owned by large international educational companies, such as Navitas or Study Group, and operate separately from the partner university. These privately owned pathway colleges promise academic or linguistic "upgrading," and explicitly advertise access to the partner institutions as part of their recruiting materials. The remaining pathway colleges (68 percent) are owned by the host institutions. These hosted pathway colleges are demarcated from the partner institution, however, with their own admissions criteria, and with students attending most or all of their classes separate from the rest of the student body.

\section{Curriculum}

Pathway colleges in Canada are also usefully differentiated based on their curriculum. Of the 69 pathway colleges in our sample, 44 ( 64 percent) offer a mixed academic and linguistic program of study. In some cases, the academic element of these programs represents a year or more of a four-year undergraduate degree, while in others it is a small number of courses. These mixed academic-language programs promise additional assistance to students who need to upgrade their linguistic or academic performance for entry to the partner institution. A smaller number of pathway colleges, 25 (36 percent), offer language-only or English for Academic Purposes (EAP) programs. In these cases, students are offered English (or in Francophone regions, French) language upgrading programs that promise to prepare them for the linguistic requirements of the partner institution. Pathway colleges that are owned and operated by a public university are slightly more likely to be EAP programs (38 percent) than those run by corporate partners (of which 32 percent are EAP programs), but mixed programs are more common in both cases. 


\section{Transfer Mechanism}

A final comparison that helps to understand this emerging institutional form is the type of pathway, or transfer mechanism, that is offered to international students. A small number of pathway colleges ( 8 of 69 , or I2 percent) require students to reapply to the partner institution after completing the pathway program. But the vast majority of pathway colleges in Canada ( 88 percent) promise students direct entry to the partner university once they have successfully completed the pathway program. All of the corporately owned pathway colleges offer direct entry to one or more institutions. Direct entry is a valuable recruiting tool that corporate partners may require before entering formal relationships with universities.

\section{The pathway college relationship is be- coming commonplace among public Canadian universities: our research re- vealed that 69 of the 96 institutions, or 72 percent of Canadian universities, had an affiliation with at least one pathway college.}

\section{Discussion}

In light of the Canadian example, pathway colleges represent a significant new institutional form. Their impact on existing institutions is unclear at this point. However, we see the potential for an increased influence of private higher education models within countries with a strong public higher education sector, like Canada. Whereas differential tuition pricing for international and domestic students has already drawn attention to corporate pricing models, the pathway college model permits institutions and their governing boards to operate a "test case" for privatization within the walls of the public university, with many international and local examples to justify moving in this direction. This effect is already visible in the similarities in form between private pathway colleges and those owned by partner institutions. This is unsurprising, considering that pathway programs represent significant income generation for institutions, both by expanding their full fee paying international student population, and by adding an additional year of enrollment per student. At a systems level, these pathways potentially usurp international student tuition dollars from community colleges, which also actively seek to recruit students from abroad. In these ways, pathway colleges are already changing the higher education landscape.
Much more research is needed to gauge the full extent of pathway college influence. Within Canada, one concern is that pathway colleges may incentivize institutions to accept students who are unlikely to succeed in the partner institution. Another is that pathway college students will not receive the same academic or student services as those at the parent institution, potentially isolating them from counselling, ombudspersons, or other support systems. Similarly, preliminary examinations suggest that the pathway college emphasis on revenue generation (and in some cases profit) means that instructors and staff are more likely to be non-union and precarious. The need for more research is pressing, as the influence of pathway colleges on the public system as a whole may mean that pressures to compete will drive other institutions to adopt similar models.

Perhaps even more important is to examine these pathway colleges in the international context. Many of the corporate partners operate in several countries, inviting questions about how different policy regimes shape the resulting pathway colleges. We question how-or ifthese multinational companies standardize their pathways across the world, which would have implications not only for how we perceive the flows of international students, but also for the extent of global corporatization of this mobility, beyond what is typically understood as a matter of recruitment agents and admissions application preparation. We see pathway colleges as representative of a shift toward a postsecondary policy landscape that enables a more interdependent, international, and "flexibilized" model, challenging the assumptions of higher education systems and the notion of separate public/private sectors.

DOI: http://dx.doi.org/10.6oI7/ihe.2018.94.10520

\section{Inclusive Internationaliza- tion: Improving Access and Equity}

\section{HANS DE WIT AND Elspeth Jones}

Hans de Wit is director of the Center for International Higher Education, Boston College, US. E-mail: dewitj@bc.edu. Elspeth Jones is emerita professor, internationalisation of higher education, Leeds Beckett University, UK. E-mail: e.jones@leedsbeckett.ac.uk.

This article is an updated version of a contribution by the authors to University World News, 8 December 2017, Issue 486. 